\title{
WestVirginiaUniversity
}

THE RESEARCH REPOSITORY @ WVU

Graduate Theses, Dissertations, and Problem Reports

2000

\section{Treatment of acid mine drainage with Weirton steel slags}

Prashant Seshadri

West Virginia University

Follow this and additional works at: https://researchrepository.wvu.edu/etd

\section{Recommended Citation}

Seshadri, Prashant, "Treatment of acid mine drainage with Weirton steel slags" (2000). Graduate Theses, Dissertations, and Problem Reports. 1088.

https://researchrepository.wvu.edu/etd/1088

This Thesis is protected by copyright and/or related rights. It has been brought to you by the The Research Repository @ WVU with permission from the rights-holder(s). You are free to use this Thesis in any way that is permitted by the copyright and related rights legislation that applies to your use. For other uses you must obtain permission from the rights-holder(s) directly, unless additional rights are indicated by a Creative Commons license in the record and/ or on the work itself. This Thesis has been accepted for inclusion in WVU Graduate Theses, Dissertations, and Problem Reports collection by an authorized administrator of The Research Repository @ WVU. For more information, please contact researchrepository@mail.wvu.edu. 


\title{
TREATMENT OF ACID MINE DRAINAGE WITH WEIRTON STEEL SLAGS
}

\author{
Prashant Seshadri \\ Thesis submitted to the College of Engineering and Mineral \\ Resources at West Virginia University \\ in partial fulfillment of the requirements for \\ the Degree of
}

Masters of Science

In

Chemical Engineering

Eung Ha Cho, Ph.D., Committee Chair

Aubrey Miller, Ph.D.

Paul Ziemkiewicz, Ph.D.

Department of Chemical Engineering

Morgantown, West Virginia

2000

Keywords: Degree of Neutralization, Weirton Steel slags, Treatment, Acid Mine Drainage, Iron precipitation 


\title{
Treatment Of Acid Mine Drainage With Weirton Steel Slags
}

\author{
Prashant Seshadri
}

\begin{abstract}
Bed experiments were conducted to treat acid mine drainage with Weirton steel slag which contained $72.22 \%$ as $\mathrm{Ca}(\mathrm{OH})_{2}$ equivalent. The Acid Mine Drainage (AMD) sample was obtained from the T\&T site located in northern West Virginia. The $\mathrm{pH}$ of the solution was 2.56 and the iron content was $89 \mathrm{ppm}$. The bed was constructed with tin-coated aluminum sheets and was 11' 8-1/4" long, 2" wide and 2" high. The experiments were conducted by charging the bed half full with the slag particles ( $4 \times 40$ mesh) and then pumping AMD solution (T\&T) through the bed. The flow rates used were $78 \mathrm{~mL} / \mathrm{min}$ and $150 \mathrm{~mL} / \mathrm{min}$. The effluent solution was collected, and analyzed for acidity and iron. Also the $\mathrm{pH}$ of the sample was measured. From the data the degree of neutralization and iron precipitation were determined. For the purpose of comparison one experiment was conducted with the same sized limestone sample.

It was found that the Weirton slag was better than limestone in treating the AMD. This may be due to distinctive neutralization mechanisms with these two solid samples. The neutralization reaction with the Weirton slag may be controlled by diffusion of hydroxyl ions through the armored ferric hydroxide layer, which is produced by the neutralization. However the reaction with the limestone may be controlled by surface reaction with the acid. Thus, the neutralization with Weirton slag is less vulnerable to armoring than the limestone. For the treatment of AMD with the Weirton slag, the degree of neutralization is higher with the lower flow rate although the iron precipitation on the bed is more.
\end{abstract}




\section{ACKNOWLEDGEMENTS}

The author would like to express his sincere gratitude and appreciation to his advisor and committee chair, Dr. Eung Ha Cho, for his patient guidance and support. The valuable suggestions and comments provided by other committee members, Dr. Paul Ziemkiewicz and Dr. Aubery Miller are greatly appreciated.

The research project WR 126 was funded by the U.S geologic survey with cost sharing between the National Research Center for Coal and Energy (NRCCE) and West Virginia University (WVU), Morgantown. The financial support from NRCCE-WVU to the author in pursuing his Master degree in Chemical Engineering, at West Virginia University is greatly appreciated. Finally I would like to thank my parents, my sister, and my friends for giving me their support and guidance during the period of my graduate study. 


\section{TABLE OF CONTENTS}

\section{Page}

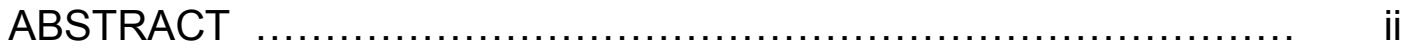

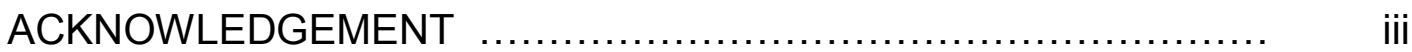

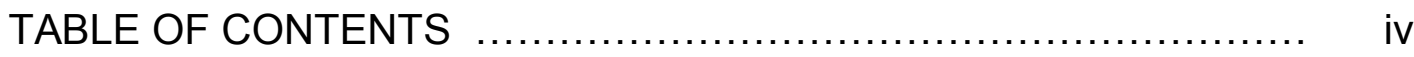

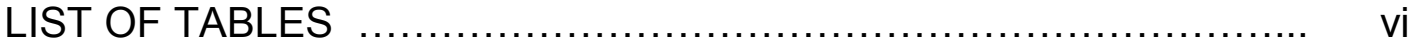

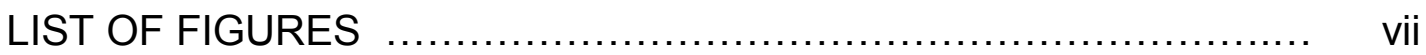

CHAPTER 1

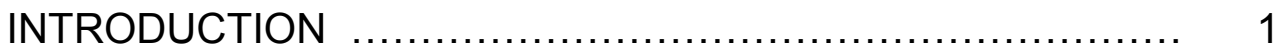

1-1 Classification of Acid Mine Drainage $\ldots \ldots \ldots \ldots \ldots \ldots .2$

1-2 Chemical Remediation of AMD $\ldots \ldots \ldots \ldots \ldots \ldots \ldots \ldots . \ldots \ldots$

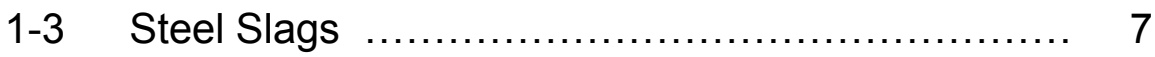

1-4 Alkalinity And Other Properties of Steel Slag ....... 8

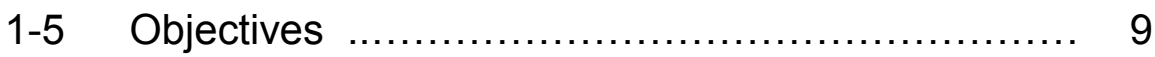

\section{CHAPTER 2}

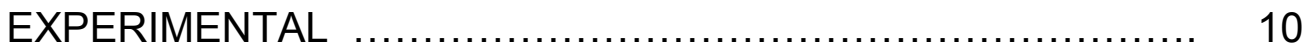

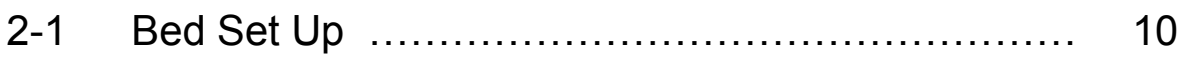

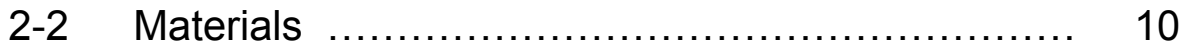

2-3 Experimental Procedures $\ldots \ldots \ldots \ldots \ldots \ldots \ldots \ldots \ldots . . \ldots \ldots \ldots$

CHAPTER 3

RESULTS AND DISCUSSION

3-1 Comparison Between Limestone and Weirton Slag .. 15

3-2 Comparison at Two Different AMD Flow Rates With

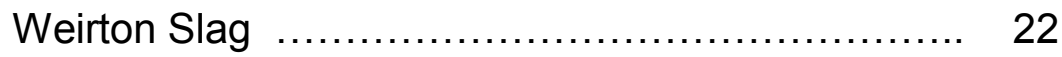




\section{TABLE OF CONTENTS}

(Continued)

\section{Page}

\section{CHAPTER 4}

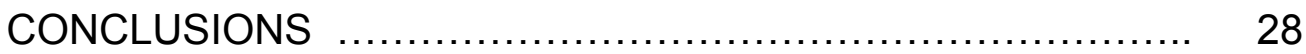

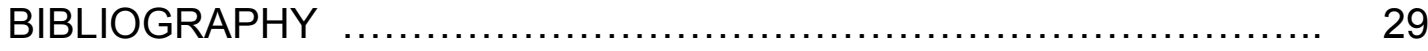

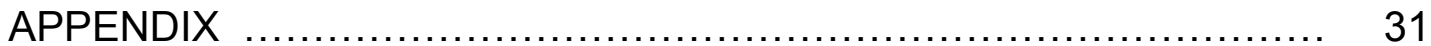




\section{LIST OF TABLES}

Table

Page

1. Various Chemicals for AMD Treatment $\ldots \ldots \ldots \ldots \ldots \ldots \ldots . \ldots$

2. Numerical Data for Figure 1, Weirton Slag $\ldots \ldots \ldots \ldots \ldots \ldots . . . . . .31$

3. Numerical Data for Figure 1, Limestone $\ldots \ldots \ldots \ldots \ldots \ldots \ldots . . . . . . .31$

4. Numerical Data for Figure 2, Weirton Slag $\ldots \ldots \ldots \ldots \ldots \ldots . . . . .32$

5. Numerical Data for Figure 2, Limestone $\ldots \ldots \ldots \ldots \ldots \ldots \ldots . . . . . . .32$

6. Numerical Data for Figure 3, Weirton Slag $\ldots \ldots \ldots \ldots \ldots \ldots . . . . . .33$

7. Numerical Data for Figure 3, Limestone $\ldots \ldots \ldots \ldots \ldots \ldots \ldots . . . . . . .33$

8. Numerical Data for Figure 4, Weirton Slag $\ldots \ldots \ldots \ldots \ldots \ldots . . . . .34$

9. Numerical Data for Figure 4, Limestone $\ldots \ldots \ldots \ldots \ldots \ldots \ldots . . . \ldots \ldots$

10. Numerical Data for Figure 5 at $150 \mathrm{~mL} / \mathrm{min} \ldots \ldots \ldots \ldots \ldots . . . . . . .35$

11. Numerical Data for Figure 5 at $78 \mathrm{~mL} / \mathrm{min} \ldots \ldots \ldots \ldots \ldots \ldots . . . . . .35$

12. Numerical Data for Figure 6 at $150 \mathrm{~mL} / \mathrm{min} \ldots \ldots \ldots \ldots \ldots . . . . . . .36$

13. Numerical Data for Figure 6 at $78 \mathrm{~mL} / \mathrm{min} \ldots \ldots \ldots \ldots \ldots \ldots . . . \ldots$

14. Numerical Data for Figure 7 at $150 \mathrm{~mL} / \mathrm{min} \ldots \ldots \ldots \ldots \ldots . . . . . . .37$

15. Numerical Data for Figure 7 at $78 \mathrm{~mL} / \mathrm{min} \ldots \ldots \ldots \ldots \ldots . . . \ldots . . . . .37$

16. Numerical Data for Figure 8 at $150 \mathrm{~mL} / \mathrm{min} \ldots \ldots \ldots \ldots \ldots . . . \ldots$

17. Numerical Data for Figure 8 at $78 \mathrm{~mL} / \mathrm{min} \ldots \ldots \ldots \ldots \ldots . . . \ldots$ 


\section{LIST OF FIGURES}

Figure

Page

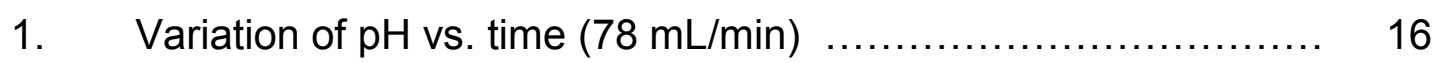

2. Degree of neutralization vs. time $(78 \mathrm{~mL} / \mathrm{min}) \quad \ldots \ldots \ldots \ldots \ldots \ldots \ldots \ldots$

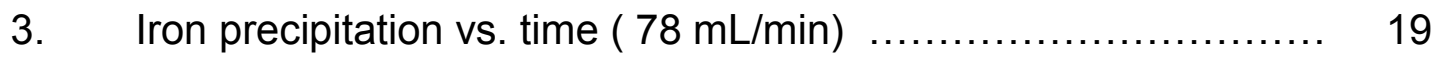

4. Iron precipitation vs. degree of neutralization $\ldots \ldots \ldots \ldots \ldots \ldots \ldots . . . \ldots . \ldots . \ldots$

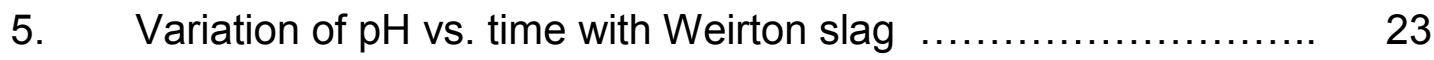

6. Degree of neutralization vs. time Weirton slag f................... 24

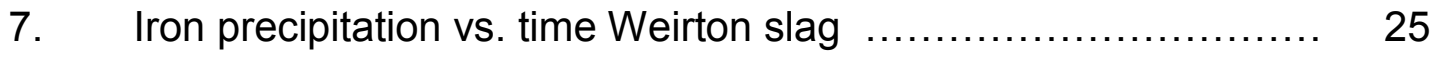

8. Iron precipitation vs. degree of neutralization Weirton slag $\ldots \ldots \ldots \quad 27$ 


\section{Chapter 1}

\section{INTRODUCTION}

\section{Production of Acid Mine Drainage}

Acid mine drainage (AMD) or acid rock drainage (ARD) is formed when certain sulfide minerals in rocks are exposed to oxidizing conditions. Much of the AMD is commonly thought to be associated with coal mining, but AMD is also a large problem where sulfides in geologic materials are encountered in highway construction, metal mines and other deep excavations.

The predominant acid producers are pyrite (U.S Code of Federal Regulations, 1985) and marcasite. Upon exposure to oxidizing conditions, some sulfide minerals in the presence of water and oxygen form highly acidic and sulfate rich drainage. Acidity levels, and metal composition and concentration depend on the type of sulfide mineral and the amount present. The following four chemical equations may explain the processes (Stumm and Morgan, 1981)

$$
\begin{aligned}
& \mathrm{FeS}_{2}+7 / 2 \mathrm{O}_{2}+\mathrm{H}_{2} \mathrm{O}=\mathrm{Fe}^{2+}+2 \mathrm{SO}_{4}{ }^{2-}+2 \mathrm{H}^{+} \\
& \mathrm{Fe}^{+2}+1 / 4 \mathrm{O}_{2}+\mathrm{H}^{+}=\mathrm{Fe}^{3+}+1 / 2 \mathrm{H}_{2} \mathrm{O} \\
& \mathrm{Fe}^{3+}+3 \mathrm{H}_{2} \mathrm{O}=\mathrm{Fe}(\mathrm{OH})_{3}+3 \mathrm{H}^{+} \\
& \mathrm{FeS}_{2}+14 \mathrm{Fe}^{3+}+8 \mathrm{H}_{2} \mathrm{O}=15 \mathrm{Fe}^{2+}+2 \mathrm{SO}_{4}{ }^{2-}+16 \mathrm{H}^{+}
\end{aligned}
$$

In equation $1, \mathrm{FeS}_{2}$ is oxidized, thereby releasing ferrous iron, sulfate $\left(\mathrm{SO}_{4}{ }^{2-}\right)$, and acid. Ferrous iron in equation 2 can be oxidized to form ferric iron $\left(\mathrm{Fe}^{3+}\right)$. Ferric iron so produced can then be either hydrolyzed to form ferric hydroxide, (equation 3), or it can directly oxidize pyrite to ferrous iron, sulfate and acid (equation 4). If any of these processes represented by the equations were 
slowed or stopped, the generation of AMD would also ease. Removal of air or water from the system would stop pyrite from being oxidized.

\section{1-1 Classification of Mine Drainage}

Mine drainage can be classified into several basic types. They are as follows:

Type 1 has little or no alkalinity $(\mathrm{pH}<4.5)$, and contains high concentrations of $\mathrm{Fe}, \mathrm{Al}, \mathrm{Mn}$, and other metals, and oxygen. This type of water is called as AMD. Type 2 has high total dissolved solids containing ferrous iron and $\mathrm{Mn}$, low oxygen content and, $\mathrm{pH}>6.0$. Upon oxidation of metal ions, the $\mathrm{pH}$ of this water drops dramatically, and the water becomes Type 1 AMD.

Type 3 has moderate to high dissolved solids, low to moderate ferrous iron and $\mathrm{Mn}$ and low or no oxygen content, $\mathrm{pH}>6.0$. It is commonly called alkaline mine drainage. Upon oxidation, the acid generated from metal hydrolysis and precipitation is neutralized by the alkalinity already present in the water.

Type 4 is a neutralized AMD with $\mathrm{pH}>6.0$ and it contains high total suspended particulates. The settling of particulates has not yet occurred. The particulate will eventually settle down if enough time is allowed.

Type 5 results from Type 4 AMD when all the suspended particulate settles down.

\section{1-2 Chemical Remediation of AMD}

Chemical remediation of $A M D$ deals with treatment of $A M D$ with alkaline chemicals to raise the $\mathrm{pH}$, neutralize acidity and precipitate metals. The chemicals include sodium hydroxide, lime, and calcium carbonate. Chemical 
treatment is an effective process; however it is a costly one because chemicals are usually expensive.

In designing a chemical treatment system, maximum values of flow rate, total suspended solids acidity (mg/L as $\mathrm{CaCO}_{3}$ equivalent), $\mathrm{Fe}$ and $\mathrm{Mn}$ concentrations in the effluent must be considered. Most active chemical treatment processes consists of an inflow pipe or ditch, a storage tank to hold the chemical, a means of adding chemicals, a settling pond to capture the metal hydroxides, and a discharge point. Table 1 lists the various chemical compounds that are used for AMD treatment process (Skousen, 2000).

Hydrated lime $\left(\mathrm{Ca}(\mathrm{OH})_{2}\right)$ is the most commonly used chemical for treating AMD. It is sold as a powder that tends to be hydrophobic, and extensive chemical mixing is required to dispense it in water. Hydrated lime is particularly useful and cost effective in large flow, high acidity situations where a lime treatment plant with mixer/aerator is constructed to mix the chemical with the water.

Bulk lime is preferred for treatment because its less expensive and easier to handle. Proper storage of hydrated lime is important in order to maintain its flow characteristics and thus ensure efficient use. The appropriate silo volume depends on the daily lime requirement. The length of time that the system will be in operation is a critical factor in determining the annual cost of a lime treatment system due to its large initial capital expenditure that can be amortized over time. 
Table 1. Various Chemicals for AMD Treatment:

\begin{tabular}{|c|c|c|}
\hline Name & Chemical Formula & Comments \\
\hline Limestone & $\mathrm{CaCO}_{3}$ & $\begin{array}{l}\text { Used in anoxic limestone } \\
\text { drains and open limestone } \\
\text { channels. }\end{array}$ \\
\hline Hydrated Lime & $\mathrm{Ca}(\mathrm{OH})_{2}$ & $\begin{array}{l}\text { Cost effective reagent but } \\
\text { requires mixing. }\end{array}$ \\
\hline Pebble Quick Lime & $\mathrm{CaO}$ & $\begin{array}{c}\text { Very reactive, needs metering } \\
\text { equipment. }\end{array}$ \\
\hline Soda Ash Briquettes & $\mathrm{Na}_{2} \mathrm{CO}_{3}$ & $\begin{array}{c}\text { System for remote location, but } \\
\text { expensive }\end{array}$ \\
\hline Caustic Soda & $\mathrm{NaOH}$ & $\begin{array}{l}\text { Very soluble, comes in liquid } \\
\text { drums, beads or flakes. } \\
\text { Cheaper in liquid form }\end{array}$ \\
\hline Ammonia & $\mathrm{NH}_{3}$ or $\mathrm{NH}_{4} \mathrm{OH}$ & $\begin{array}{l}\text { Very reactive or soluble also } \\
\text { purchased as aqua ammonia. }\end{array}$ \\
\hline
\end{tabular}

Caustic Soda $(\mathrm{NaOH})$ is often used in remote locations (e.g., where electricity is unavailable), and in low flow ( $<100 \mathrm{gpm})$, high acidity situations. It is commonly the chemical of choice if manganese concentrations in the AMD are high because caustic soda can raise the water $\mathrm{pH}$ as high as to 13 . The system can be gravity fed by dripping caustic directly into the AMD. Caustic is very soluble in water, disperses rapidly, and raises the $\mathrm{pH}$ of water quickly. It should 
be applied to the surface of the water, because the chemical is denser than water it would sink resulting in less effective treatment. The major drawbacks for using liquid caustic for AMD treatment are high cost, dangers in handling the chemical, and high sludge volumes.

Tanks holding caustic soda can range from 1900 to $30,000 \mathrm{~L}$ (500 to $8,000)$ gallons. The discharge line is fixed at the bottom of the tank and transports the caustic solution to the seep, ditch or pond. A gate valve placed at the end of the discharge line controls the flow rate.

Liquid caustic can freeze during winter months, but there are several options available to deal with the freezing problem. These include burying the tank, installing a tank heater, switching from a $20 \%$ to a $50 \%$ caustic solution, using a freeze-proof solution containing some potassium hydroxide $(\mathrm{KOH})$, and utilizing solid caustic. Burying is an expensive option, because the operator must then comply with the stringent EPA laws (for underground storage). Heaters must be replaced quite often because of the corrosive effects of caustic. Of these options, the three most economical solutions are switching to the $50 \%$ caustic solution, adding some $\mathrm{KOH}$, and utilizing solid caustic. Switching from a $20 \%$ to a $50 \%$ caustic lowers the freezing point from $0^{\circ} \mathrm{C}$ to about $-37^{\circ} \mathrm{C}$. The addition of $\mathrm{KOH}(35 \%$ of the solution) also lowers the freezing point. Solid caustic, which may be delivered in 32-Kg (70-pound) drums, beads, or flakes, has been used with good success. It is possible to monitor the rate at which the solid caustic dissolves by metering the flow of water into the drum. Solid caustic can be used to make liquid caustic. 
Calcium Carbonate (limestone, $\mathrm{CaCO}_{3}$ ) has been used for decades to raise $\mathrm{pH}$ and precipitate metals in AMD. It has the lowest material cost and is the safest, easiest to handle of the among AMD chemicals, and produces the most compact and easy to handle sludge material. Unfortunately, its successful application has been limited because of its low solubility especially in cold weather, its tendency to armor when added to AMD, and its inability to raise $\mathrm{pH}$ to sufficient levels for manganese removal. For water streams with lower $\mathrm{pH}$ and lower mineral acidity (low metal concentrations), finely-ground limestone may be dumped in streams directly or the limestone may be ground using water-powered rotating drums and metered into the stream. Limestone has also been used to treat AMD in anaerobic (anoxic limestone drains) and aerobic environments (open limestone channels). These two techniques are especially useful where compliance with National Pollutant Discharge Elimination System (NPDES) limits is not required. They are both being utilized specially in abandoned mine land reclamation projects and by operators wishing to reduce the chemical treatment costs (Faulkner, 1996).

The equilibrium reaction for the limestone dissolution is fairly straightforward.

$$
\begin{aligned}
& \mathrm{CaCO}_{3}+2 \mathrm{H}^{+}=\mathrm{Ca}^{2+}+\mathrm{H} \mathrm{O}+\mathrm{CO}_{2} \\
& \mathrm{CaCO}_{3}+\mathrm{H}^{+}=\mathrm{Ca}^{2+}+\mathrm{HCO}_{3}^{-}
\end{aligned}
$$

When limestone is added to a strong acid, the $\mathrm{pH}$ increases and the rate is determined primarily by initial acid concentration. But the dissolved iron in AMD not only coats limestone surfaces but also hinders dissolution rates. Iron increases the required neutralization time (Loeppert and Hossner, 1984). 
The reactions for limestone armoring are as follows:

$$
\begin{aligned}
& \mathrm{Fe}^{3+}+3 \mathrm{H}_{2} \mathrm{O}=\mathrm{Fe}(\mathrm{OH})_{3}(s)+3 \mathrm{H}^{+} \\
& \mathrm{Fe}^{3+}+\mathrm{H}_{2} \mathrm{O}=\mathrm{Fe}(\mathrm{OH})^{2+}+\mathrm{H}^{+} \\
& \mathrm{Fe}^{3+}+2 \mathrm{H}_{2} \mathrm{O}=\mathrm{Fe}(\mathrm{OH})_{2}^{+}+2 \mathrm{H}^{+} \\
& \mathrm{Fe}^{3+}+3 \mathrm{H}_{2} \mathrm{O}=\mathrm{Fe}(\mathrm{OH})_{2}{ }^{0}+3 \mathrm{H}^{+} \\
& \mathrm{Fe}^{3+}+4 \mathrm{H}_{2} \mathrm{O}=\mathrm{Fe}(\mathrm{OH})_{4}{ }^{-}+4 \mathrm{H}^{+}
\end{aligned}
$$

The coating or armoring decreases the available surface area for

limestone dissolution. Also,the filling of pore spaces by the yellow boy retards the diffusion of acid to the limestone surface. Thus these two effects resulting from the precipitation of ferric hydroxide decreases the neutralization of AMD. The armored limestone is estimated to be $4-62 \%$ as effective as fresh limestone (Pearson and McDonnell, 1975; Ziemkiewicz, 1997).

\section{1-3 Steel Slags}

Slags are nonmetallic byproducts resulting from many metalurgical operations and consist primarily of calcium, magnesium, and aluminum silicates in various combinations. Specifically iron and steel slags result from iron and steel manufacturing. In making steel, iron ore or scrap metal are melted in combination with limestone, dolomite or lime. Pure iron is soft, bends easily under loads and has limited uses. Adding small amounts of carbon, nickel, maganese and other elements converts the iron into various alloys of steel. There are different grades of steels ranging from carbon steel to high grade stainless steel. 
Production of steel requires the removal of excess silicon and carbon by oxidation from pig or crude iron. Also, the presence of any aluminium or phosphorus causes problems because they make the steel weak, brittle or difficult to process. To overcome this we can add limestone or dolomite-these calcium compounds complex with aluminum, silicon and phosphorus to form slag. The slag floats to the top of the melt, is poured off and placed in piles for disposal.

\section{1-4 Alkalinity And Other Properties Of Steel Slags}

Steel slags are calcium alumina-silicates oxides formed at the melting point of iron. These compounds contain elements such as sulfur, selenium, carbon, cadmium, lead, copper and mercury. Most of the residuals are encased within a glassy matrix. This matrix is soluble and can release calcium and manganese oxides which can drive the $\mathrm{pH}$ of the dissolving fluid to 10 or 11 . Since slag is a coarse glass, it will maintain high permeability $\left(\sim 4.5310^{-2}\right.$ $\mathrm{cm} / \mathrm{sec}$ ) regardless of how much water has passed through it (Skousen and Ziemkiewicz, 1997). The permiability of this material can be reduced if it is compacted or ground up into smaller particles.

One of the advantages of steel slags over limestone is that it will not absorb $\mathrm{CO}_{2}$ from the air and convert back to relatively insoluble limestone according to the reaction.

$$
\mathrm{Ca}(\mathrm{OH})_{2}+\mathrm{CO}_{2}=\mathrm{CaCO}_{3}+\mathrm{H}_{2} \mathrm{O} .
$$

This is a major advantage that slag has over limestone since it means that slag can be left outside and still achieve high degree of alkalinity upon 
dissolution. The reason steel slag does not absorb $\mathrm{CO}_{2}$ from the atmosphere is because $\mathrm{CaO}$ in the slag is bonded with $\mathrm{SiO}_{2}$ to form a CaO-SiO${ }_{2}$ complex. This is important from its practical application because the complex is dissolved to give alkalinity with its $\mathrm{CaO}$ content release regardless of the length of time it has been stored outside. Typical slags contain a range of $12-20 \% \mathrm{Fe}, 40-50 \% \mathrm{CaO}$ and approximately $15 \% \mathrm{SiO}_{2}$ (Collins and Ciesielski, 1994).

The neutralization potential of steel slag range from $45-78 \%$ (Skousen and Ziemkiewicz, 1997). Neutralization potential is determined by sulfuric acid titration of a slurry of finely ground waste material from its natural $\mathrm{pH}$ to $\mathrm{apH}$ of 3.5. The neutralization potential is expressed as an equivalent $\mathrm{CaCO}_{3}$ weight percentage, e.g., $\mathrm{Kg}$ of $\mathrm{CaCO}_{3}$ per ton of waste (Hutchinson and Ellison, 1992).

\section{1-5 Objectives}

The objective of this research is to compare limestone to steel slags in their treatment capcities for AMD. Such factors are considered in the comparison as degree of neutralization, extent of armoring and specific relationship between these two for each neutralizing agent. Also, the objective is to determine the AMD treatment capacity of Weirton slag at different flow rates. 


\section{Chapter 2}

\section{EXPERIMENTAL}

\section{2-1 Bed Set Up}

Experiments were conducted in a bed, which could simulate a conceptual process for treatment of AMD in the field. The bed was made by connecting two 6-ft tin-coated aluminum sheets. The dimensions were 11' 8-1/4 long, 2" wide and 2" high. These two sheets were connected with super glue and then the connected portion was coated with resin glue. The bed was coated with four-tofive layers of paint and was varnished before each experiment to ensure that the AMD did not dissolve the aluminum bed itself. Also the two ends of the bed were embanked by a 2" $\times 2$ " acrylic sheet at the inlet and by a 1 " $\times 2$ " acrylic sheet at the outlet. The bed was then filled with the solid sample of either limestone or Weirton steel slag to an approximate height of 1". It was compacted to ensure uniformity of height. Using a peristaltic pump, the AMD was pumped at a specific flow rate on the bed.

\section{2-2 Materials}

The AMD sample used in the experiment was obtained from T\&T mine site, which is near Morgantown, WV. The analysis of the AMD sample showed that the $\mathrm{pH}$ was 2.56 , and the acidity was $935 \mathrm{mg} / \mathrm{L}$, as $\mathrm{CaCO}_{3}$ equivalent. The acidity was calculated using the amount of $\mathrm{NaOH}$ solution required to neutralize the AMD sample at $\mathrm{pH}$ 8.3. The indicator was m-cresol purple solution. However, the acidity value was conveniently used as a concentration of acid for analysis of data in this study. Acidity of the AMD was determined to be 0.0136 molar. An 
atomic absorption unit was used to analyze the metal contents in the AMD, and the results showed that iron was $89 \mathrm{ppm}$; manganese, $2.3 \mathrm{ppm}$; zinc, $1.3 \mathrm{ppm}$; nickel, 0.4 ppm; cobalt, 0.3 ppm; magnesium, 46.3 ppm; and calcium, 90 ppm. As mentioned previously the solid sample used for the experiment were Weirton slag and limestone. Weirton slag raw sample was obtained from Weirton Steel Company, Weirton, WV. The limestone sample was obtained Greenbrier Limestone Company about 10 miles from Morgantown, $\mathrm{WV}$. These raw samples were screened and 4340 mesh $(0.425-4.75 \mathrm{~mm})$ fractions were used for the experiments.

These samples were analyzed by a chemical method, in which a known quantity of sample was leached with $6 \mathrm{~N} \mathrm{HCl}$ in a bottle for a week, the slurry was filtered and the filtrate was titrated with $\mathrm{NaOH}$ at $\mathrm{pH}$ 8.3. The amount of $\mathrm{HCl}$ consumed was used to calculate $\mathrm{OH}^{-}$and $\mathrm{Ca}(\mathrm{OH})_{2}$ equivalents for Weirton sample. This value was $33.15 \%$ and $72.22 \%$, respectively. In the case of limestone, $\mathrm{OH}^{-}$and $\mathrm{CaCO}_{3}$ equivalents were determined. They were $28.9 \%$ and $85 \%$, respectively.

\section{2-3 Experimental Procedures}

Four bed experiments were conducted, three with Weirton slag and one with limestone using the bed. The bed surface was first varnished and allowed to dry. The sample was then mixed thoroughly, and a known quantity of the sample was poured on the bed. It was then compacted to ensure uniformity of height in the bed. The height for all the four experiments was maintained at approximately one inch. 
Prior to each of the two experiments with Weirton steel slag the bed was first filled with distilled water, and slurry samples were collected from different parts of the bed at various times. In the bed the alkaline content from the solid sample was released to the distilled water. These samples were then filtered using two No.1 filter papers. This was done to ensure that no suspended solid matter was present in the filtrate. A known quantity of this sample; usually $5 \mathrm{ml}$ was then titrated with $0.12 \mathrm{M} \mathrm{HCl}$ solution in the burette. It was found that the alkalinity level in the leachate reached a saturation concentration of $0.0264 \mathrm{M} \mathrm{OH}^{-}$ in 2 hours. This level is the same concentration as the saturation concentration from the hydrated lime, suggesting that steel slag behaves similarly to hydrated lime.

The experiment was then started, by pumping the AMD into the bed. The flow rate was $78 \mathrm{~mL} / \mathrm{min}$ or $150 \mathrm{~mL} / \mathrm{min}$. The AMD flowed over the bed, and was collected at the discharge end. The samples were collected in narrow time intervals in the early stages (e.g., $20 \mathrm{~min}$ ) and then in wide time intervals (e.g., $1 \mathrm{hr})$ in the later stages.

The sample collected from the bed was measured for $\mathrm{pH}$. When the $\mathrm{pH}$ was above 3 or precipitation of iron hydroxide was visible, it was filtered using two No. 1 filter papers. Then a $25 \mathrm{~mL}$ solution was taken from the filtrate and analyzed for its acidity. As the end point neared, it was found that the iron hydroxide precipitation interfered with the color change. Hence the sample was re-filtered using No.1 filter paper and the filtration resumed with newly obtained 
filtrate. For the analyses of iron, the samples were diluted and analyzed using an atomic absorption unit.

In the next experiment, limestone sample was used. The limestone bed was not filled with distilled water, unlike in the case of the first two experiments. This was because limestone did not release significant alkalinity to the distilled water. The procedures for this experiment as to sample analysis were same as those of the first two experiments. The time period for this experiment was much shorter (4 hours) because limestone was armored much more quickly.

The last experiment was conducted using Weirton steel slag. The bed was not filled with distilled water, which was the same condition as for the experiment with limestone. This was done in order to compare the results with both limestone and Weirton slag directly.

The mass of the sample in the bed for each experiment varied from 10656 $\mathrm{g}$ to $10700 \mathrm{~g}$, or $0.42 \%$. However the mass of the limestone was $8687.9 \mathrm{~g}$ which is less than that of Weirton slag by about $19 \%$. This was because the limestone has a lower bulk density than that of Weirton steel slag.

The iron concentrations obtained from atomic absorption were used to numerically calculate the iron precipitation as a function of time. A trapezoidal numerical method was used for the calculations. A new terminology has been devised to determine the degree of neutralization. The degree of neutralization has been used for this purpose and it takes the form:

$$
\text { Degree of neutralization }=\left(\left[\mathrm{H}^{+}\right]_{0}-\left[\mathrm{H}^{+}\right]\right) /\left[\mathrm{H}^{+}\right]_{0}
$$

where $\left[\mathrm{H}^{+}\right]_{0}$ and $\left[\mathrm{H}^{+}\right]$are initial acidity, and acidity at any time respectively. 
Equation 13 conveniently chooses a scale of $\mathrm{pH}$ up to 8.3 because the acidity measured is based on titration at that $\mathrm{pH}$. Thus, the degree of neutralization is one at $\mathrm{pH} 8.3$ and zero when the acidity value of the effluent is the same as in the influent AMD. This degree of neutralization does not evaluate the neutralization capacity above $\mathrm{pH}$ 8.3. However, it is considered that the $\mathrm{pH}$ is an upper value for normal AMD treatment. 


\section{Chapter 3}

\section{RESULTS AND DISCUSSION}

The experimental results obtained from the bed experiments were used to plot $\mathrm{pH}$ vs. time, degree of neutralization vs. time, iron precipitation vs. time and degree of neutralization vs. iron precipitation. The data for each experiment are mentioned at the end in the appendix. Figures 1 through 4 show the comparison of the data of experiments conducted with Weirton steel slag and limestone samples. Figures 5 through 8 show the comparison of data of experiments conducted at flow rates of $78 \mathrm{~mL} / \mathrm{min}$ and $150 \mathrm{~mL} / \mathrm{min}$ with Weirton slag sample.

\section{3-1 Comparison between Limestone and Weirton Slag}

Figure 1 is a plot of $\mathrm{pH}$ vs. time with the Weirton slag and limestone at an AMD flow rate of $78 \mathrm{~mL} / \mathrm{min}$. The $\mathrm{pH}$ values were higher with the Weirton slag than with the limestone for the same time period. Weirton slag has higher $\mathrm{OH}^{-}$ content than limestone as $33.15 \%$ and $28.9 \%$, respectively. Also, the mass of the Weirton slag in the bed was about $19 \%$ more than that of limestone. Combining these two, the $\mathrm{OH}^{-}$content in the Weirton slag is about $29 \%$ higher than that in the limestone. However, neutralization depends on the surface area of the solid particles rather than the $\mathrm{OH}^{-}$content in the sample since the neutralization reaction takes place on the surface of the solid particle. The total surface area of the limestone in the bed is higher than that of the Weirton slag because the bulk density of the limestone is lower than that of the other solid. Nevertheless, the higher $\mathrm{pH}$ with the Weirton slag as shown in Figure 1 suggests that it is a better neutralizing agent than the limestone. 
Figure 1. Variation of $\mathrm{pH}$ with time $(78 \mathrm{ml} / \mathrm{min}$ flowrate)

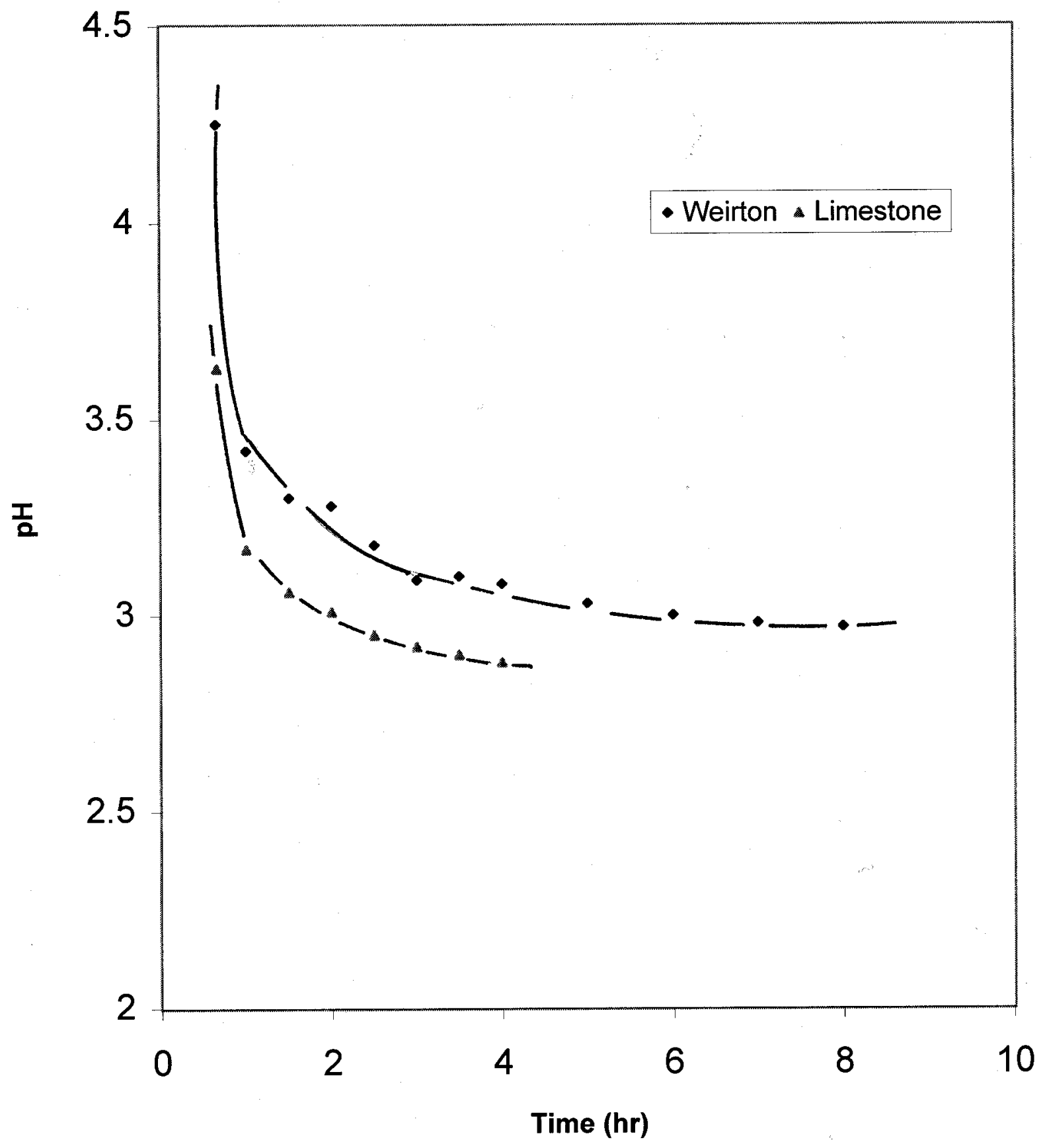


Figure 2 is a plot of degree of neutralization vs. time for the Weirton slag and the limestone samples at a constant flow rate of $78 \mathrm{~mL} / \mathrm{min}$. From the graph we can see that the degree of neutralization with the Weirton slag is greater than that with the limestone. The degree of neutralization with the Weirton slag decreases as time goes on and shows that it decreases from 0.49 at 2 hours to 0.39 and 4 hours. However, the degree of neutralization with the limestone decreases more rapidly than that with the Weirton slag, and shows that it decreases from 0.41 at 2 hours to 0.24 at 4 hours. The decrease in the degree of neutralization is undoubtedly due to the armoring effect of ferric hydroxide. The slope of the line then represents the armoring effect.

Figure 3 is a plot of iron precipitation vs. time, with the limestone and Weirton steel slag at a flow rate of $78 \mathrm{~mL} / \mathrm{min}$. The amount of iron precipitated is the sum of the amount settled on the bed and that overflowed by the discharging stream. However, the latter amount appeared to be much smaller than the former amount. As can be seen from the graph, the iron precipitation with the Weirton slag is greater than that with the limestone and shows that it is $0.64 \mathrm{~g}$ at 4 hours with the limestone and $0.906 \mathrm{~g}$ at 4 hours with the Weirton slag, or higher by 28.6\%. The disparity in iron precipitation seems to be due to the difference in $\mathrm{pH}$ values as shown in Figure 1. In spite of the disparity the degree of neutralization with the Weirton slag is higher than that with limestone. This means that the Weirton slag neutralizes the AMD better than 
Figure 2. Degree of neutralization vs. time ( 78 $\mathrm{ml} / \mathrm{min}$ flowrate )

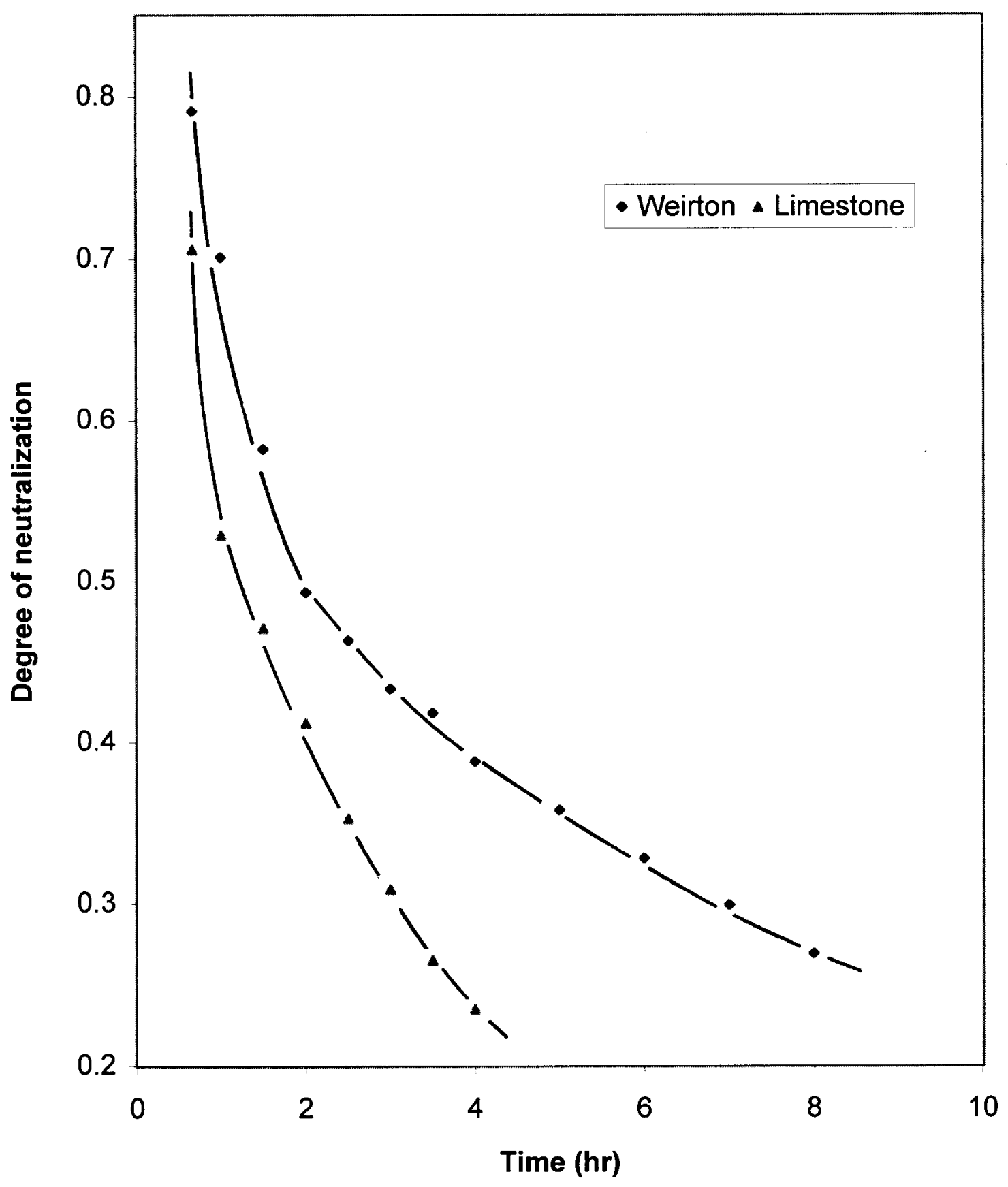


Figure 3. Iron precipitation vs. time ( $78 \mathrm{ml} / \mathrm{min}$ flowrate )

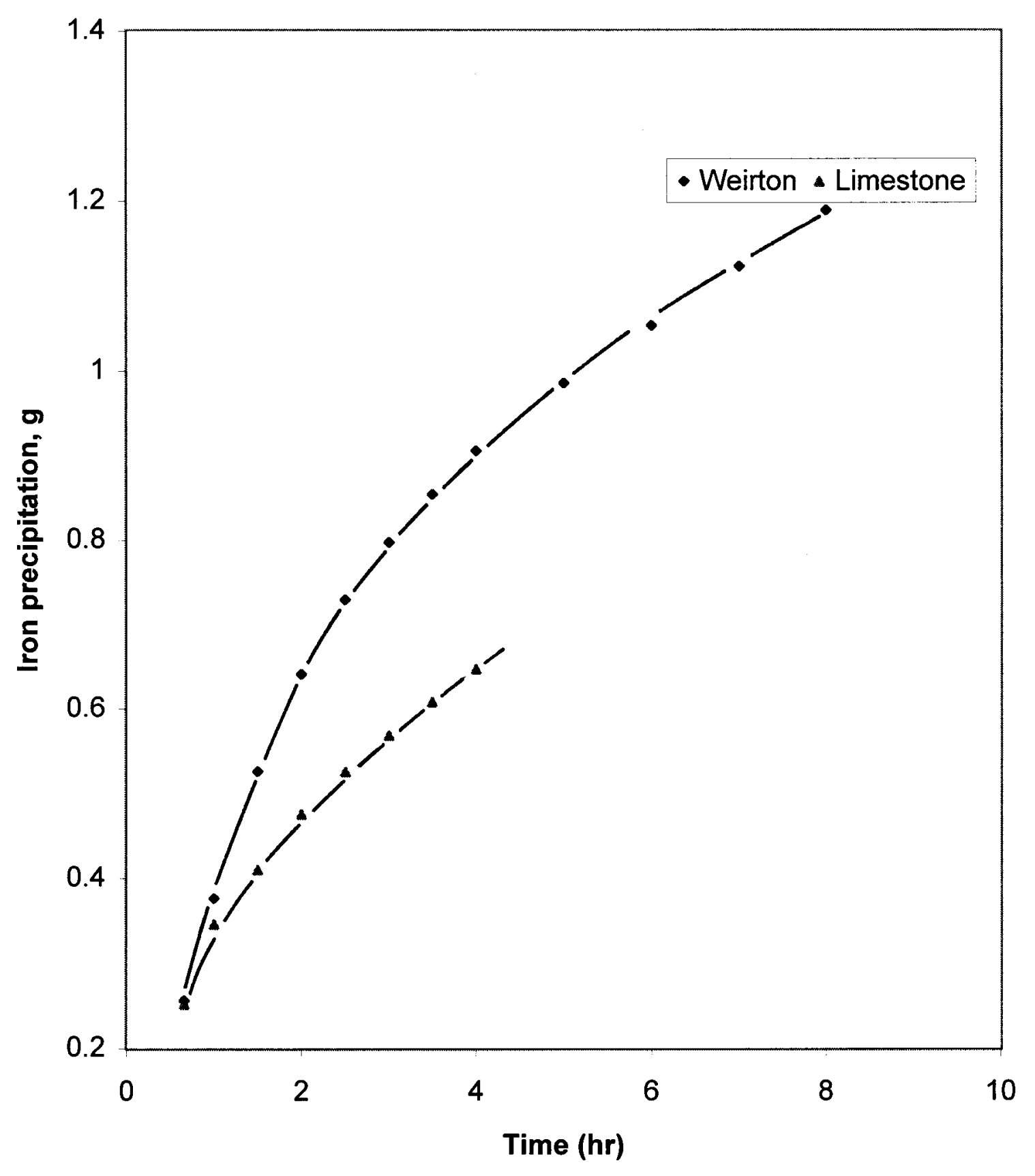


the limestone, and suggests that the neutralizing mechanism may be different in both cases.

Figure 4 is a plot of iron precipitation vs. degree of neutralization. From the graph we can see that for the same amount of iron precipitation, the degree of neutralization is higher with Weirton steel slag than that with the limestone. This phenomenon is a key point in this study. In other words, the neutralizing mechanism with the Weirton slag is different from the one with the limestone. It is speculated that since limestone does not release appreciable alkalinity in solution, the neutralizing mechanism is based on a series of reactions in which hydrogen ion in the AMD diffuses to the surface of the limestone particle and reacts with it. Thus, neutralization is very sensitive to armoring because it reduces available surface area of the limestone particle.

It is also speculated that since Weirton slag releases its alkalinity into solution, the hydroxyl ion released from the Weirton slag particle diffuse through the armored ferric hydroxide layer and react with acid. This mechanism depends on the diffusion of hydroxyl ions through the armored ferric hydroxide layer and does not depend on chemical reaction with which the surface area plays a ratecontrolling role. Thus, the neutralization with the Weirton slag is less sensitive to the armoring effect as can be seen from Figure 4. 
Figure 4. Iron precipitation vs. degree of neutralization ( $78 \mathrm{ml} / \mathrm{min}$ flowrate )

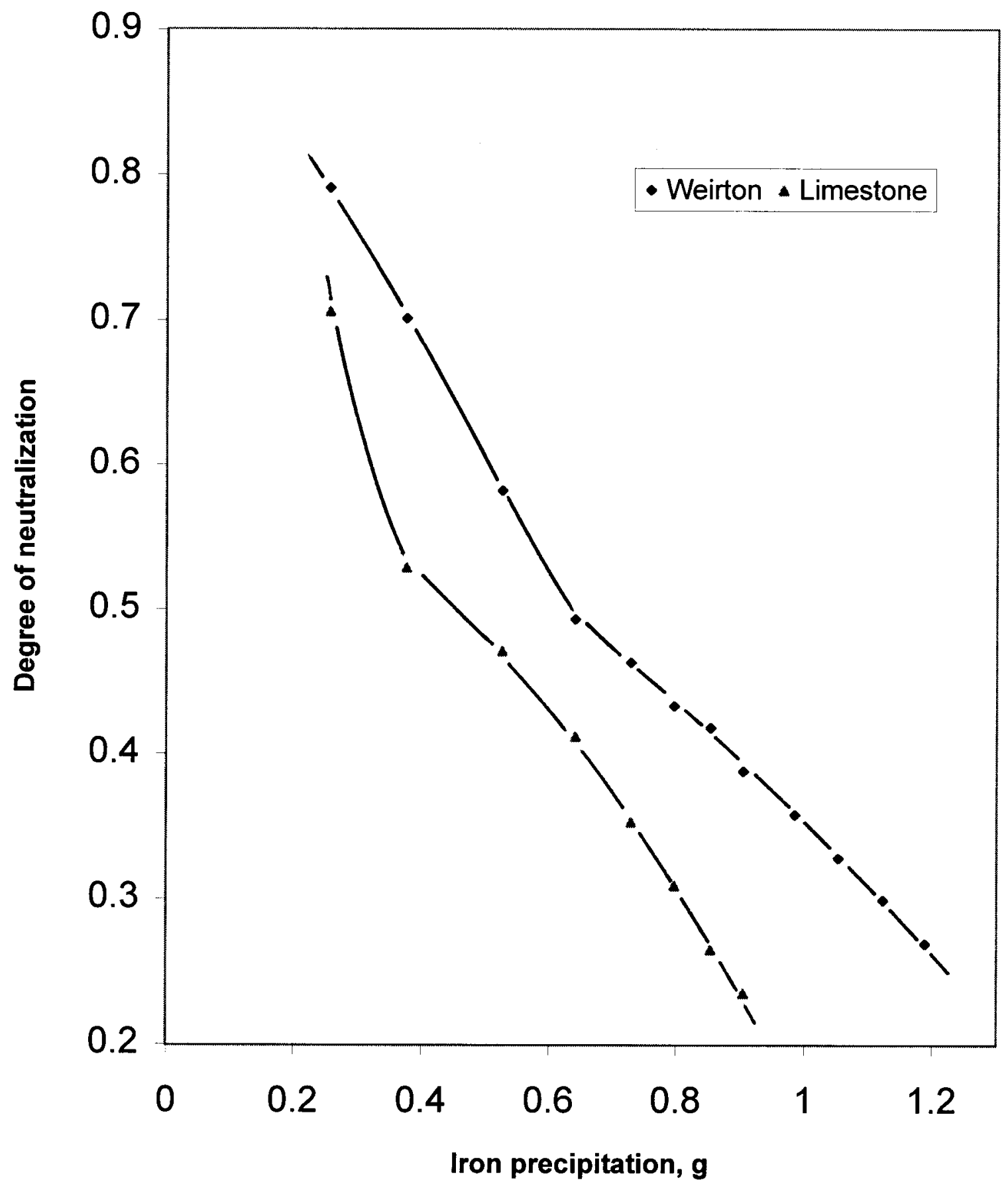




\section{3-2 Comparison at Two Different AMD Flow Rates with Weirton Slag}

Figure 5 is a plot of $\mathrm{pH}$ vs. time with the Weirton slag at different flow rates. The flow rates were $78 \mathrm{~mL} / \mathrm{min}$ and $150 \mathrm{~mL} / \mathrm{min}$. The results from the graph show that the $\mathrm{pH}$ values were higher with the lower flow rate. The $\mathrm{pH}$ values were 2.9 at 5 hours with $150 \mathrm{~mL} / \mathrm{min}$ and 3.3 at 5 hours with $78 \mathrm{~mL} / \mathrm{min}$. The reason is undoubtedly due to the difference in retention time of AMD in the bed. More alkalinity is released with the less flow rate or with the higher retention time.

Figure 6 is a plot of degree of neutralization vs. time for the Weirton steel slag at two different flow rates of $78 \mathrm{~mL} / \mathrm{min}$ and $150 \mathrm{~mL} / \mathrm{min}$. The degree of neutralization depends on the amount of alkalinity released from the sample, which also depends on the retention time. The lower the flow rate, the higher the retention time and the higher the degree of neutralization. This can be seen from the figure.

Figure 7 is a plot of iron precipitation vs. time using Weriton slag at two different flow rates of $78 \mathrm{~mL} / \mathrm{min}$ and $150 \mathrm{~mL} / \mathrm{min}$. The results from the graph show us that the iron precipitation at the lower flow rate is higher than that at the higher flow rate. The iron precipitation would depend on the $\mathrm{pH}$ of the discharged solution sample, which would in turn depend on the alkalinity released from the solid sample. One can see that the degree of neutralization and the $\mathrm{pH}$ of the discharged solution were higher at the lower flow rate than at the higher flow rate. This means that the increase in retention time actually increases the 
Figure 5. Variation of $\mathrm{pH}$ with time with weirton sample

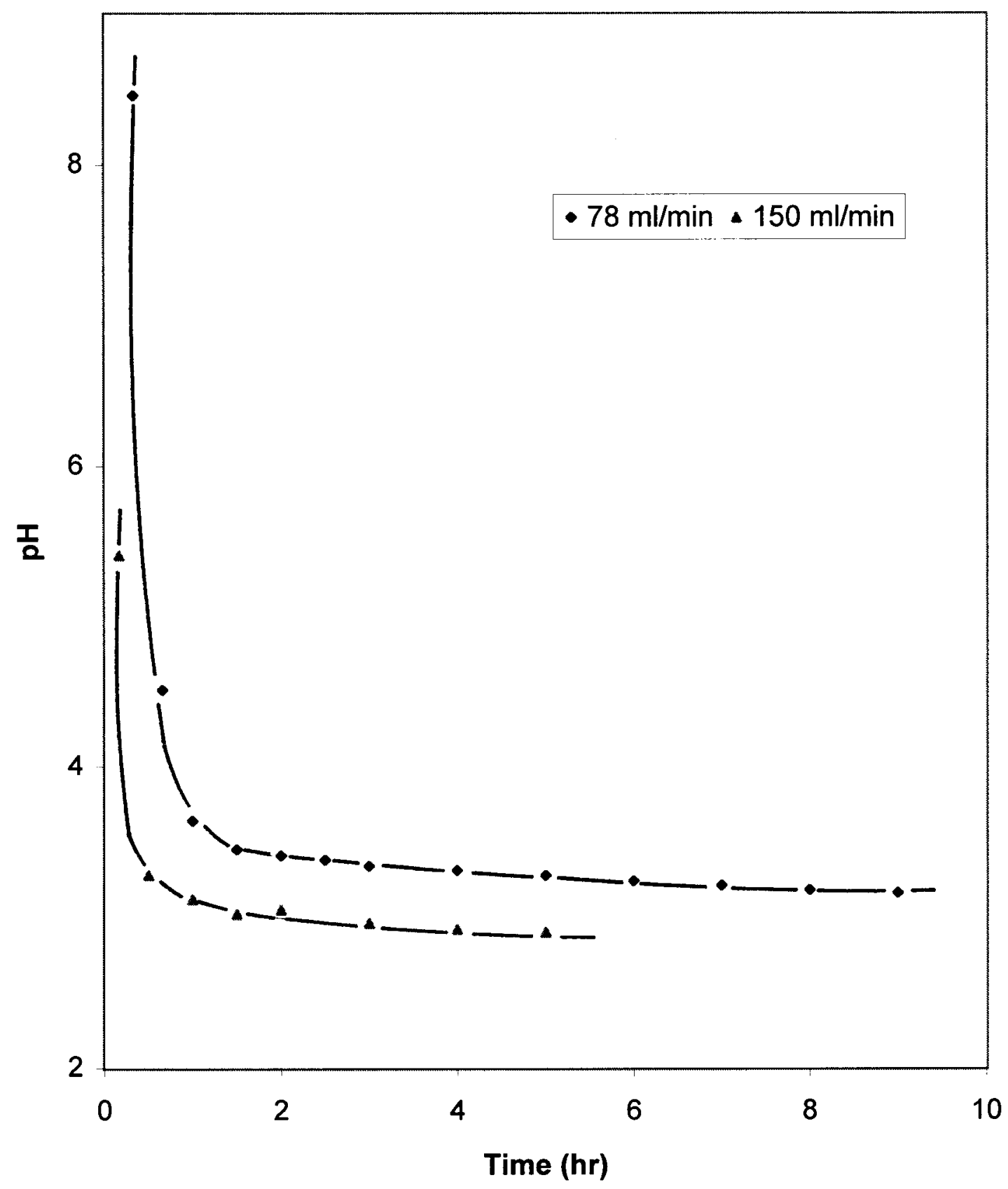


Figure 6. Degree of neutralization vs. time with weirton sample

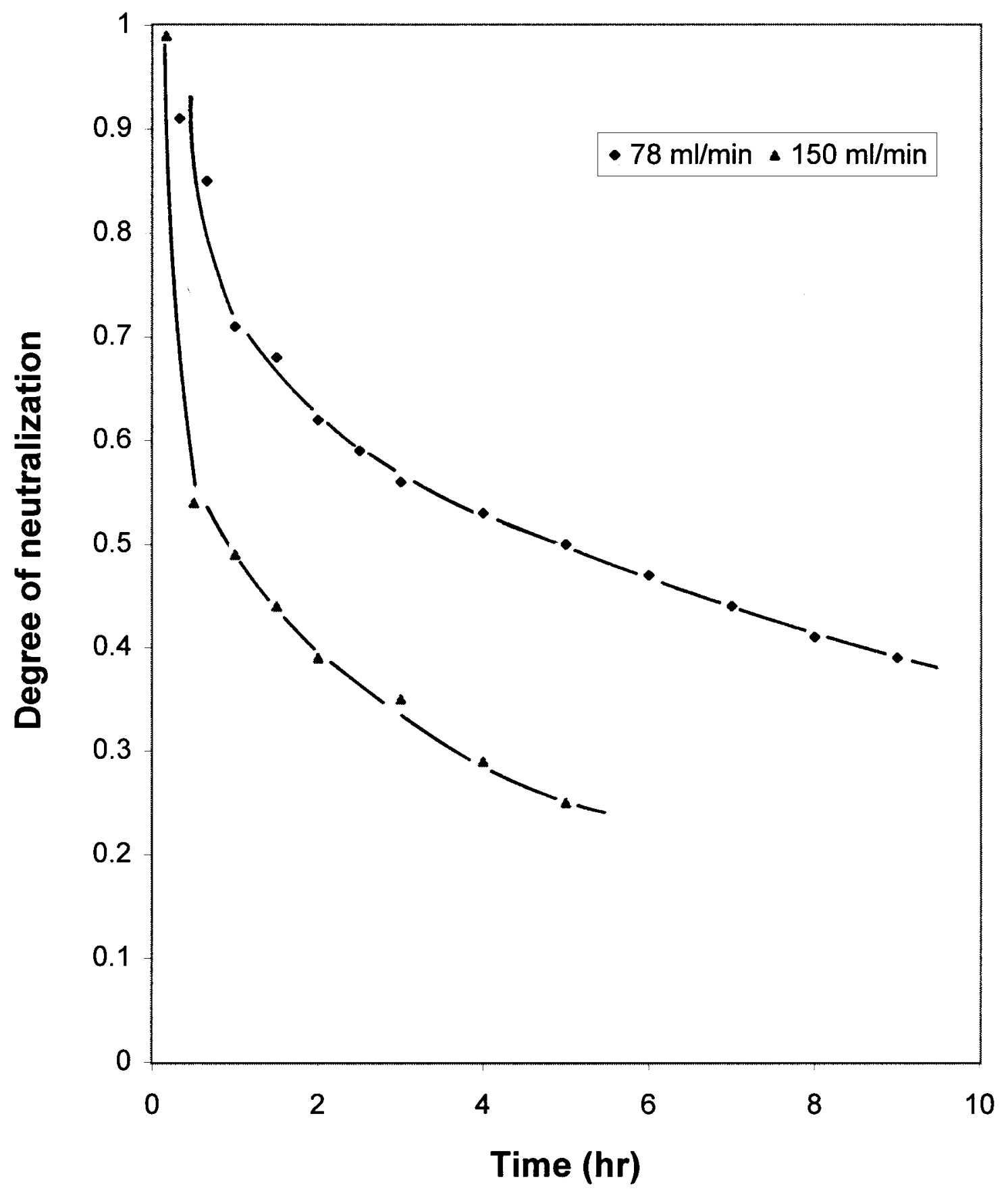


Figure 7. Iron precipitation vs. time with weirton sample

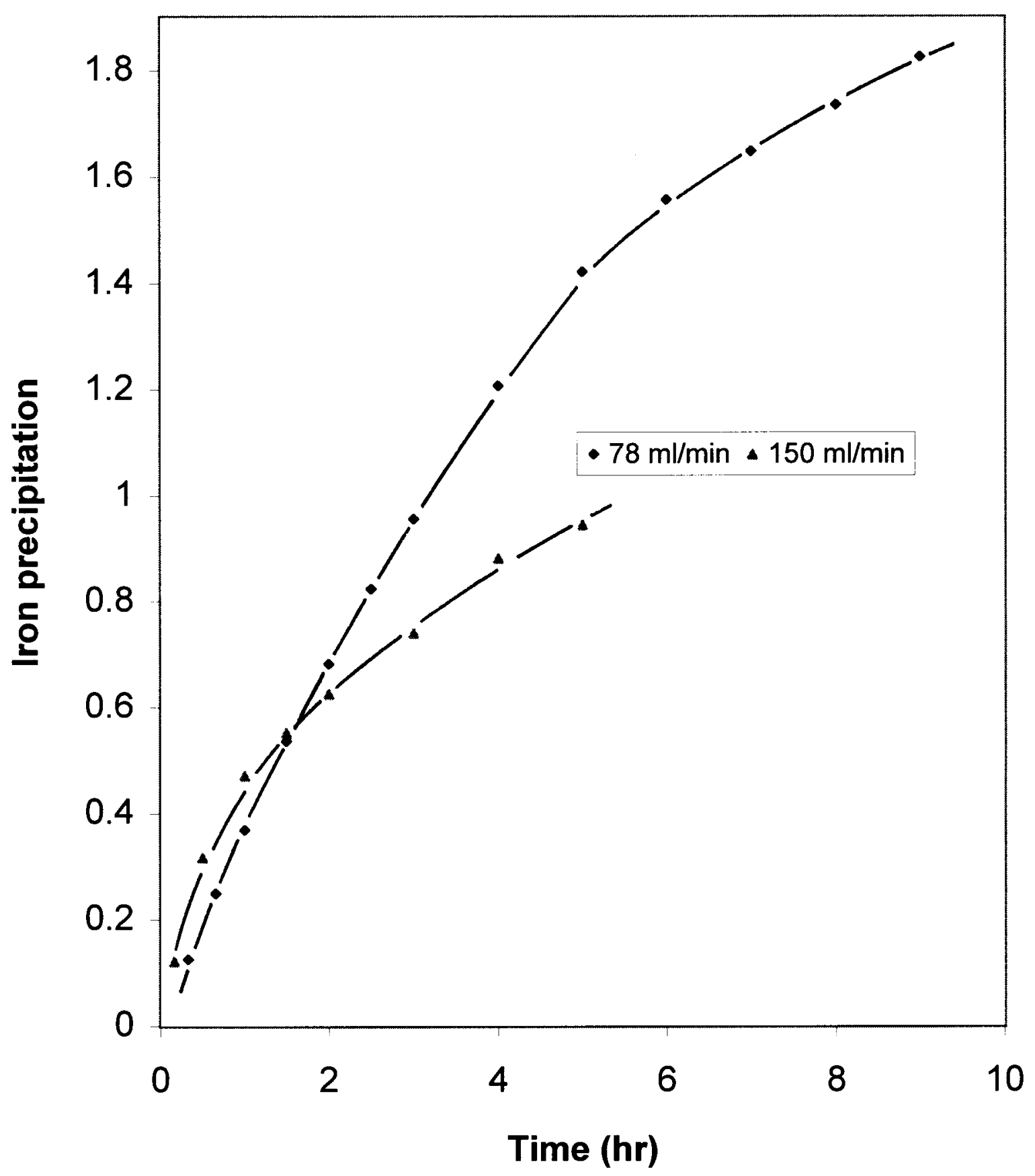


precipitation of iron in the AMD. Thus, for this bed experiment, using a lower flow rate is more beneficial for AMD treatment.

Figure 8 is a plot of iron precipitation vs. degree of neutralization for the Weirton slag at two flow rates of $78 \mathrm{~mL} / \mathrm{min}$ and $150 \mathrm{~mL} / \mathrm{min}$. The degree of neutralization decreases as iron precipitation increases and also increases as the retention time increases. Thus, it can be said that the degree of neutralization is a function of both iron precipitation and retention time. 
Figure 8. Iron precipitation vs. degree of neutralization with weirton sample

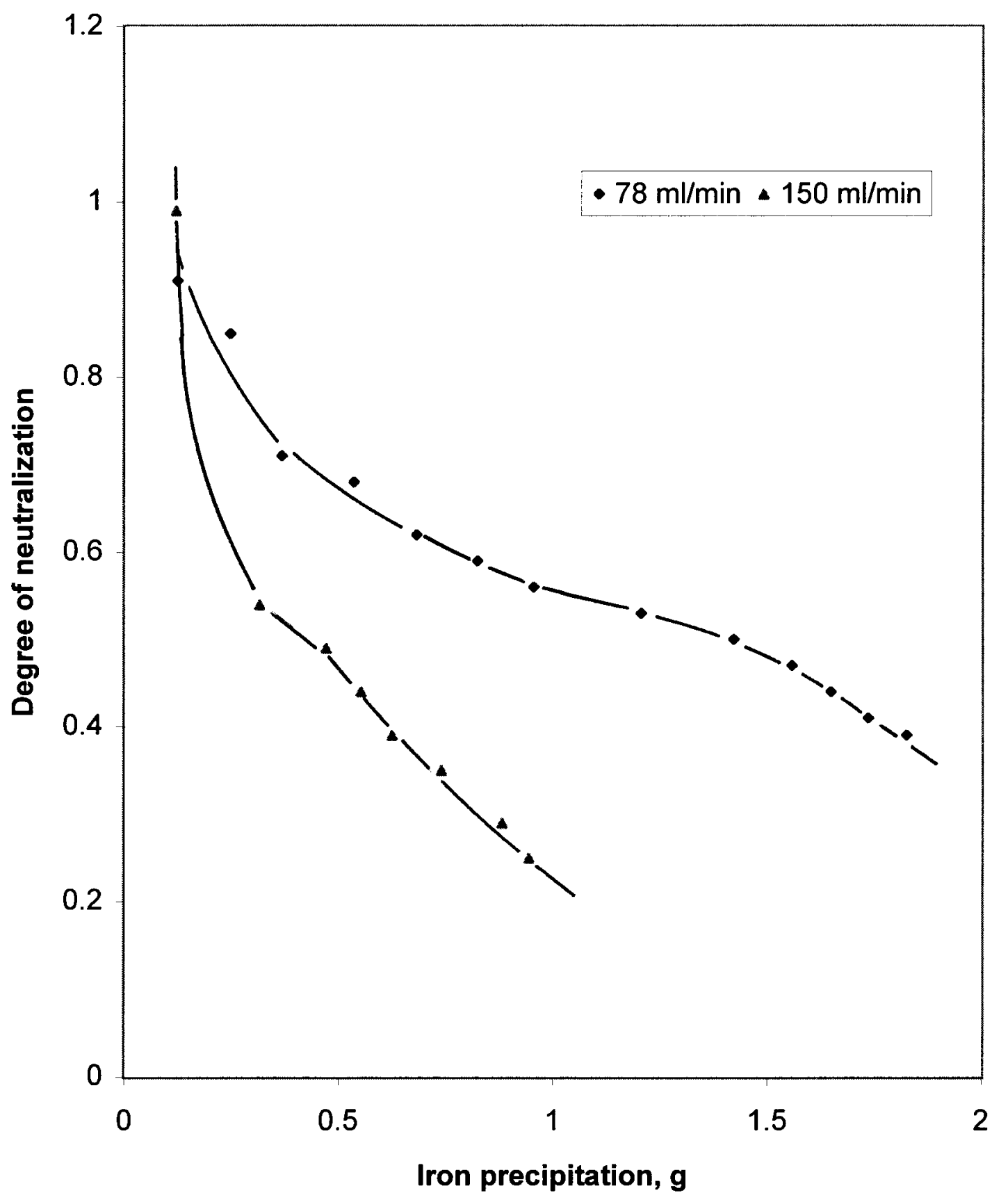




\section{Chapter 4}

\section{CONCLUSIONS}

From the results of the experiment conducted to treat AMD with limestone sample the following conclusions can be drawn:

1. The Weirton steel slag is better than limestone in treating AMD. More specifically the Weirton slag results in higher degree of neutralization of AMD than limestone while the former induces more armoring than the latter.

2. The neutralization mechanism of AMD with the Weirton slag seems to be distinctively different from that with the limestone. The neutralization reaction with the Weirton slag maybe based on diffusion of hydroxyl ions through the armored layer while that with the limestone maybe based on surface reaction with the acid. Thus, the neutralization with Weirton slag is less vulnerable to armoring than the limestone.

3. For the treatment of AMD with the Weirton slag, the degree of neutralization is higher with the lower flow rate although the iron precipitation on the bed is more. This means that the retention time of the AMD in the bed can offset the armoring effect. 


\section{BIBLIOGRAPHY}

Collins, R.J. and Ciesielski, S.K., 1994, "Recycling and Use of Waste Materials and By-Products in Highway Construction," National Cooperative Highway Research Program Synthesis of Highway Practice pp 199, Transportation Research Board, Washington, D.C.

Di, P., 1994, "Soluble Manganese Removal and Heavy Metal lons Adsorption by Manganese Oxide-Coated Media," M.S.Thesis, West Virginia University, pp. 3-5, 73-77.

Faulkner, B.B., 1996, "Acid Mine Drainage Treatment Recommendations," West Virginia Mining and Reclamation Association, Charleston, WV.

Hedin, R.S. and Nairn, R.W., 1992, "Designing and Sizing Passive Mine Drainage Treatment Systems," Proceedings, Thirteenth Annual West Virginia Surface Mine Drainage Task Force Symposium, Morgantown, WV, April 8-9.

Hutchison, I.P.G. and Ellison, R.D., 1992, "Mine Waste Management," Lewis Publishers, New York, pp 170.

Loeppert, R.H. and Hossner, L.R., 1984, "Reactions of $\mathrm{Fe}^{+2}$ and $\mathrm{Fe}^{+3}$ with Calcite. Clays and Clay Minerals," 32(3): pp 213-222.

Pearson, F.H. and McDonnell, A.J., 1975, "Use of Crushed Limestone to Neutralize Acid Wastes," J. Env. Eng. Div. ASCE. 103: pp 139-158.

Qingyun, S, Louis, M. M, Jr., and Skousen, J.,2000, "Effects of Armoring on Limestone Neutralization of AMD," Proceedings, Twenty First Annual West Virginia Surface Mine Drainage Task Force Symposium, Morgantown, WV, April 4-5.

Skousen, J., Professor College of Agriculture and Forestry West Virginia University, Personal Conversations, May 2000.

Skousen, J., Lilly, R., and Hilton, T., 1993, "Special Chemicals for Treating Acid Mine Drainage," Green Lands 23(3): pp 34-41. 
Stumm, W. and Morgan, J.J., 1981, Aquatic Chemistry, $2^{\text {nd }}$ ed., John Wiley \& Sons, Inc., New York, pp 525-538.

U.S. Code of Federal Regulations, 1985, Title 40 - Protection of the Environment; Chapter 1 - Environment Protection Agency; Part 434 - Coal Mining Point Source Category; Subpart C - Acid of Ferruginous Mine Drainage.

Ziemkiewicz, P. and Skousen, J.,1997, "The Use of Steel Slag in Acid Mine Drainage Treatment and Control," Green Lands, pp. 46-56. 


\section{APPENDIX}

NUMERICAL DATA

Table 2. Numerical Data for Figure 1, Weirton Slag

\begin{tabular}{|c|c|}
\hline Time (mins) & $\mathrm{pH}$ \\
\hline 40 & 4.25 \\
\hline 60 & 3.42 \\
\hline 90 & 3.30 \\
\hline 120 & 3.28 \\
\hline 150 & 3.18 \\
\hline 180 & 3.09 \\
\hline 210 & 3.10 \\
\hline 240 & 3.08 \\
\hline 300 & 3.03 \\
\hline 360 & 3.00 \\
\hline 420 & 2.98 \\
\hline 480 & 2.97 \\
\hline
\end{tabular}

Table 3. Numerical Data for Figure 1, Limestone

\begin{tabular}{|c|c|}
\hline Time (mins) & $\mathrm{pH}$ \\
\hline 40 & 3.63 \\
\hline 60 & 3.17 \\
\hline 90 & 3.06 \\
\hline 120 & 3.01 \\
\hline 150 & 2.95 \\
\hline 180 & 2.92 \\
\hline 210 & 2.90 \\
\hline 240 & 2.88 \\
\hline
\end{tabular}


Table 4. Numerical Data for Figure 2, Weirton Slag

\begin{tabular}{|c|c|c|}
\hline Time (mins) & Acidity (molar) & Degree of Neutralization \\
\hline 0 & 0.0134 & 0.791 \\
\hline 40 & 0.0028 & 0.701 \\
\hline 60 & 0.0040 & 0.582 \\
\hline 90 & 0.0056 & 0.493 \\
\hline 120 & 0.0068 & 0.463 \\
\hline 150 & 0.0072 & 0.433 \\
\hline 180 & 0.0076 & 0.418 \\
\hline 210 & 0.0078 & 0.388 \\
\hline 240 & 0.0082 & 0.358 \\
\hline 300 & 0.0086 & 0.328 \\
\hline 360 & 0.0090 & 0.299 \\
\hline 420 & 0.0094 & 0.269 \\
\hline 480 & 0.0098 & \\
\hline
\end{tabular}

Table 5. Numerical Data for Figure 2, Limestone

\begin{tabular}{|c|c|c|}
\hline Time (mins) & Acidity (molar) & Degree of Neutralization \\
\hline 0 & 0.0136 & 0 \\
\hline 40 & 0.0040 & 0.706 \\
\hline 60 & 0.0064 & 0.529 \\
\hline 90 & 0.0072 & 0.471 \\
\hline 120 & 0.0080 & 0.412 \\
\hline 150 & 0.0088 & 0.353 \\
\hline 180 & 0.0094 & 0.309 \\
\hline 210 & 0.010 & 0.265 \\
\hline 240 & 0.0104 & 0.235 \\
\hline
\end{tabular}


Table 6. Numerical Data for Figure 3, Weirton Slag

\begin{tabular}{|c|c|}
\hline Time (mins) & Amount of iron precipitation, $g$ \\
\hline 40 & 0.256 \\
\hline 60 & 0.376 \\
\hline 90 & 0.526 \\
\hline 120 & 0.641 \\
\hline 150 & 0.729 \\
\hline 180 & 0.797 \\
\hline 210 & 0.854 \\
\hline 240 & 0.905 \\
\hline 300 & 0.985 \\
\hline 360 & 1.053 \\
\hline 420 & 1.123 \\
\hline 480 & 1.189 \\
\hline
\end{tabular}

Table 7. Numerical Data for Figure 3, Limestone

\begin{tabular}{|c|c|}
\hline Time (mins) & Amount of iron precipitation, $g$ \\
\hline 40 & 0.252 \\
\hline 60 & 0.346 \\
\hline 90 & 0.418 \\
\hline 120 & 0.476 \\
\hline 150 & 0.526 \\
\hline 180 & 0.569 \\
\hline 210 & 0.608 \\
\hline 240 & 0.647 \\
\hline
\end{tabular}


Table 8. Numerical Data for Figure 4, Weirton Slag

\begin{tabular}{|c|c|c|}
\hline Amount of iron precipitation, $\mathrm{g}$ & Acidity (molar) & Degree of Neutralization \\
\hline 0.256 & 0.0028 & 0.791 \\
\hline 0.376 & 0.0040 & 0.701 \\
\hline 0.526 & 0.0056 & 0.582 \\
\hline 0.641 & 0.0068 & 0.493 \\
\hline 0.729 & 0.0072 & 0.463 \\
\hline 0.797 & 0.0076 & 0.433 \\
\hline 0.854 & 0.0078 & 0.418 \\
\hline 0.905 & 0.0082 & 0.388 \\
\hline 0.985 & 0.0086 & 0.358 \\
\hline 1.053 & 0.0090 & 0.328 \\
\hline 1.123 & 0.0094 & 0.299 \\
\hline 1.189 & 0.0098 & 0.269 \\
\hline
\end{tabular}

Table 9. Numerical Data for Figure 4, Limestone

\begin{tabular}{|c|c|c|}
\hline Amount of iron precipitation, $g$ & Acidity (molar) & Degree of Neutralization \\
\hline 0.252 & 0.0040 & 0.706 \\
\hline 0.346 & 0.0064 & 0.529 \\
\hline 0.418 & 0.0072 & 0.471 \\
\hline 0.476 & 0.0080 & 0.412 \\
\hline 0.526 & 0.0088 & 0.353 \\
\hline 0.569 & 0.0094 & 0.309 \\
\hline 0.608 & 0.010 & 0.265 \\
\hline 0.647 & 0.0104 & 0.235 \\
\hline
\end{tabular}


Table 10. Numerical Data for Figure 5 at $150 \mathrm{~mL} / \mathrm{min}$

\begin{tabular}{|c|c|}
\hline Time $($ mins $)$ & $\mathrm{pH}$ \\
\hline 10 & 5.41 \\
\hline 30 & 3.28 \\
\hline 60 & 3.12 \\
\hline 90 & 3.05 \\
\hline 120 & 3.02 \\
\hline 180 & 2.96 \\
\hline 240 & 2.92 \\
\hline
\end{tabular}

Table 11. Numerical Data for Figure 5 at $78 \mathrm{~mL} / \mathrm{min}$

\begin{tabular}{|c|c|}
\hline Time (mins) & $\mathrm{pH}$ \\
\hline 20 & 8.46 \\
\hline 40 & 4.51 \\
\hline 60 & 3.64 \\
\hline 90 & 3.45 \\
\hline 120 & 3.41 \\
\hline 150 & 3.38 \\
\hline 180 & 3.34 \\
\hline 240 & 3.31 \\
\hline 300 & 3.27 \\
\hline 360 & 3.24 \\
\hline 420 & 3.21 \\
\hline 480 & 3.18 \\
\hline
\end{tabular}


Table 12. Numerical Data for Figure 6 at $150 \mathrm{~mL} / \mathrm{min}$

\begin{tabular}{|c|c|c|}
\hline Time (mins) & Acidity (molar) & Degree of Neutralization \\
\hline 0 & 0.0135 & 0 \\
\hline 10 & 0.00015 & 0.99 \\
\hline 30 & 0.0062 & 0.54 \\
\hline 60 & 0.0069 & 0.49 \\
\hline 90 & 0.0076 & 0.44 \\
\hline 120 & 0.0082 & 0.39 \\
\hline 180 & 0.0088 & 0.35 \\
\hline 240 & 0.0096 & 0.29 \\
\hline 300 & 0.0102 & 0.25 \\
\hline
\end{tabular}

Table 13. Numerical Data for Figure 6 at $78 \mathrm{~mL} / \mathrm{min}$.

\begin{tabular}{|c|c|c|}
\hline Time (mins) & Acidity (molar) & Degree of Neutralization \\
\hline 0 & 0.0136 & 0 \\
\hline 20 & 0.0013 & 0.91 \\
\hline 40 & 0.0020 & 0.85 \\
\hline 60 & 0.0040 & 0.71 \\
\hline 90 & 0.0044 & 0.68 \\
\hline 120 & 0.0052 & 0.62 \\
\hline 150 & 0.0056 & 0.59 \\
\hline 180 & 0.0060 & 0.56 \\
\hline 240 & 0.0064 & 0.53 \\
\hline 300 & 0.0068 & 0.50 \\
\hline 360 & 0.0072 & 0.47 \\
\hline 420 & 0.0076 & 0.44 \\
\hline 480 & 0.0080 & 0.41 \\
\hline 540 & 0.0082 & 0.39 \\
\hline
\end{tabular}


Table 14. Numerical Data for Figure 7 at $150 \mathrm{~mL} / \mathrm{min}$

\begin{tabular}{|c|c|}
\hline Time (mins) & Amount of iron precipitation, $\mathrm{g}$ \\
\hline 10 & 0.121 \\
\hline 30 & 0.317 \\
\hline 60 & 0.471 \\
\hline 90 & 0.552 \\
\hline 120 & 0.625 \\
\hline 180 & 0.774 \\
\hline 240 & 0.882 \\
\hline 300 & 0.945 \\
\hline
\end{tabular}

Table 15. Numerical Data for Figure 7 at $78 \mathrm{~mL} / \mathrm{min}$

\begin{tabular}{|c|c|}
\hline Time (mins) & Amount of iron precipitation, $g$ \\
\hline 20 & 0.125 \\
\hline 40 & 0.249 \\
\hline 60 & 0.369 \\
\hline 90 & 0.536 \\
\hline 120 & 0.682 \\
\hline 150 & 0.824 \\
\hline 180 & 0.956 \\
\hline 240 & 1.207 \\
\hline 300 & 1.422 \\
\hline 360 & 1.557 \\
\hline 420 & 1.648 \\
\hline 480 & 1.735 \\
\hline 540 & 1.825 \\
\hline
\end{tabular}


Table 16. Numerical Data for Figure 8 at $150 \mathrm{~mL} / \mathrm{min}$

\begin{tabular}{|c|c|c|}
\hline Amount of iron precipitation, $g$ & Acidity (molar) & Degree of Neutralization \\
\hline 0.121 & 0.00015 & 0.99 \\
\hline 0.317 & 0.0062 & 0.54 \\
\hline 0.471 & 0.0069 & 0.49 \\
\hline 0.552 & 0.0076 & 0.44 \\
\hline 0.625 & 0.0082 & 0.39 \\
\hline 0.774 & 0.0088 & 0.35 \\
\hline 0.882 & 0.0096 & 0.29 \\
\hline 0.945 & 0.0102 & 0.25 \\
\hline
\end{tabular}

Table 17. Numerical Data for Figure 8 at $78 \mathrm{~mL} / \mathrm{min}$

\begin{tabular}{|c|c|c|}
\hline Amount of iron precipitation, $g$ & Acidity (molar) & Degree of Neutralization \\
\hline 0.125 & 0.0013 & 0.91 \\
\hline 0.249 & 0.0020 & 0.85 \\
\hline 0.369 & 0.0040 & 0.71 \\
\hline 0.536 & 0.0044 & 0.68 \\
\hline 0.682 & 0.0052 & 0.62 \\
\hline 0.824 & 0.0056 & 0.59 \\
\hline 0.956 & 0.0060 & 0.56 \\
\hline 1.207 & 0.0064 & 0.53 \\
\hline 1.422 & 0.0068 & 0.50 \\
\hline 1.557 & 0.0072 & 0.47 \\
\hline 1.648 & 0.0076 & 0.44 \\
\hline 1.735 & 0.0080 & 0.41 \\
\hline 1.825 & 0.0082 & 0.39 \\
\hline
\end{tabular}

